\title{
АНАЛІЗ СТІЙКОСТІ СИСТЕМИ КЕРУВАННЯ НА БАЗІ ДВОКАНАЛЬНОГО НЕЧІТКОГО РЕГУЛЯТОРА
}

\author{
Новіков П. В. ${ }^{1}$, Штіфзон О. Й. ${ }^{2}$ \\ ${ }^{1,2}$ Національний технічний університет України "Київський політехнічний інститут імені Ігоря Сікорського"; м. Київ, \\ пр. Перемоги, 37 \\ ORCID: ${ }^{1}$ http://orcid.org/0000-0002-2790-5809, ${ }^{2}$ http://orcid.org/0000-0003-0011-4617 \\ E-mail: ${ }^{1}$ p.novikov@kpi.ua, ${ }^{2}$ oshtifzon@gmail.com
}

Copyright (C) 2018 by author and the journal "Automation of technological and business - processes. This work is licensed under the Creative Commons Attribution International License (CC BY). http://creativecommons.org/licanses/by/4.0
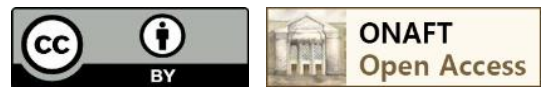

\section{DOI: https://doi.org/10.15673/atbp.v12i1.1700}

Анотація. В статті розглянуто підхід аналізу стійкості нелінійної систем керування, щзо базується на нечіткій логіці. Метою статті є аналіз існуючих методів дослідження нелінійних інтелектуальних систем керування, щзо базуються на апараті теорї нечітких множин; розробка методики аналізу стійкості системи керування, щзо базується на двоканальному нечіткому регуляторі; дослідження стійкості системи автоматичного регулювання температурного режиму котлоагрегату ТЕС, побудованої на основі двоканального нечіткого регулятора. Проведено аналіз існуючих проблем $i$ методів дослідження нечітких систем керування. Для нечітких регуляторів загальноприйнятих, універсальних методів перевірки стійкості не виявлено. Існуючі методи аналізу нечітких систем керування не надають обтрунтування стійкості, а лише забезпечують можливість перевірки працездатності за існуючих збурень, вихідних сигналів тощо. Для аналізу стійкості системи з двоканальним нечітким регулятором розроблено методику, щзо трунтується на приведенні нелінійної системи до еквівалентної адаптивної системи $з$ підлаштуванням параметрів лінійного регулятора. Обгрунтовано можливість представлення схеми двоканального нечіткого регулятора як еквівалентної до адаптивного I- або ПІ-регулятора. Отримано аналітичні залежності між вихідними параметрами двоканального нечіткого регулятора і налаштуваннями ПІ-регулятора. Для всього діапазону зміни вхідних параметрів двоканального нечіткого регулятора згідно отриманих залежностей визначені комбінації налаштувань еквівалентного ПІ-регулятора. Розраховані запаси стійкості системи керування для всіх ділянок перехідного прочесу системи регулювання температурного режиму прямоточного котлоагрегату в усьому діапазоні зміни навантаження енергоблоку. Визначені ділянки перехідного процесу, на яких система керування працює за межею стійкості, забезпечуючи при изьому збільшення швидкості реакиї на збурення порівняно зі стандартним ПІДрегулятором з фіксованими налаштуваннями.

Abstract. The article deals with the approach of stability analysis of nonlinear control systems based on fuzzy logic. The purpose of the article is to analyze the existing methods of investigation of nonlinear intelligent control systems based on the fuzzy set theory; development of a methodology for analysis of stability of a control system based on a two-channel fuzzy controller; study of the stability of the control system of the temperature mode of the boiler unit of the TPP, built on the basis of a two-channel fuzzy controller. The analysis of existing problems and methods of investigation of fuzzy control systems is carried out. For fuzzy controllers conventional and universal methods of stability analysis have not been found. Existing methods of fuzzy control systems analysis do not provide a justification for stability, but only provide the ability to test the performance of existing disturbances, output signals, etc. To evaluate the stability of a system with a two-channel fuzzy controller, a methodology has been developed that is based on presenting the nonlinear system to an equivalent adaptive system with adjusting the parameters of the linear controller. The possibility of presenting a two-channel fuzzy controller circuit as equivalent to an adaptive Integral or PI controller is substantiated. Analytical dependencies between the output parameters of the two-channel fuzzy controller and the settings of the PI controller were obtained. For the whole range of change of input parameters of the two-channel fuzzy controller, according to the obtained equations, combinations of settings of the equivalent PI controller are determined. The stability margins of the control system for all sections of the transient process of the temperature control system of the direct-flow boiler unit in the whole range of load changes of the power unit are calculated. The areas of transient processes on which the control system operates beyond stability are determined. At the same time system increases the rate of disturbance response compared to a standard fixed-tuned PID controller. 
http://www.atbp.onaft.edu.ua/

Ключові слова: стійкість, нечітка логіка, адаптація, система керування.

Key words: stability, fuzzy logic, adaptation, control system.

\section{Вступ}

Забезпечення стійкості систем зі зворотним зв'язком є одним з фундаментальних завдань побудови системи керування. Тільки система, що задовольняє певним технологічним критеріям стійкості дозволяє досягати поставленої мети керування. Наприклад, швидке реагування на довільні збурення або швидке досягнення заданого режиму роботи об'єкта. Ці вимоги в рівній мірі відносяться і до систем з fuzzy-регуляторами.

При застосуванні fuzzy-керування, особливо на об'єктах, що мають підвищені вимоги до безпеки та надійності функціонування, необхідна ретельна оцінка стійкості в усій області змін координат системи. Таким чином дослідження i забезпечення стійкості систем 3 fuzzy-керуванням є обов'язковою задачею. Необхідною базою для перевірки стійкості системи є наявність достатньо точних математичних моделей об'єкта керування [1].

\section{Аналіз літературних даних і постановка проблеми}

Для нечітких регуляторів загальноприйнятих, універсальних методів перевірки стійкості на сьогоднішній день не існує, але є спроби адаптації класичних аналітичних підходів [2]. Основна складність аналітичного дослідження стійкості нечітких регуляторів полягає в їх суттєвій нелінійності, неможливості лінеаризації. У тому випадку, якщо математична модель об'єкта управління відсутня, говорити про проведення теоретичного дослідження системи управління взагалі немає сенсу.

Розглянуті в роботі [2] методи аналізу нечітких систем управління мають істотні недоліки, в більшості своїй не дають суворого обгрунтування стійкості, а скоріше забезпечують можливість перевірки працездатності, коли точно відомі початкові умови, збурення та вхідні впливи на систему.

У разі непридатності аналітичних методик можливим рішенням може стати застосування емпіричних, експериментальних підходів. Їх основна ідея полягає в необхідності синтезу і подальшого комп'ютерного аналізу нечітких моделей об'єкта управління і регулятора. Застосування сучасної обчислювальної техніки, програмних пакетів моделювання, таких як MATLAB, дозволяє вести всебічний аналіз складних багатовимірних систем, незалежно від числа сигналів, що на них впливають $[3,4]$.

Недоліком емпіричних методів є істотна складність або неможливість узагальнення отриманих на їх основі результатів. Вони просто підтверджують стійкість системи для конкретних умов, які розглядаються в ході моделювання [4].

Пошук методів, що дозволяють проводити дослідження стійкості систем управління на основі апарату нечіткої логіки, ведеться давно, але більшість способів $є$ адаптацією методів дослідження стійкості 3 класичної теорії управління.

Метою дослідження є розробка прийнятної і відносно простої методики аналізу стійкості системи керування, що базується на двоканальному нечіткому регуляторі.

\section{Аналіз структурної схеми двоканального нечіткого регулятора}

Для аналізу стійкості системи 3 двоканальним нечітким регулятором (рис. 1) в роботі [5] запропоновано методику, що дозволяє адаптувати методи оцінки стійкості з лінійної теорії автоматичного керування.

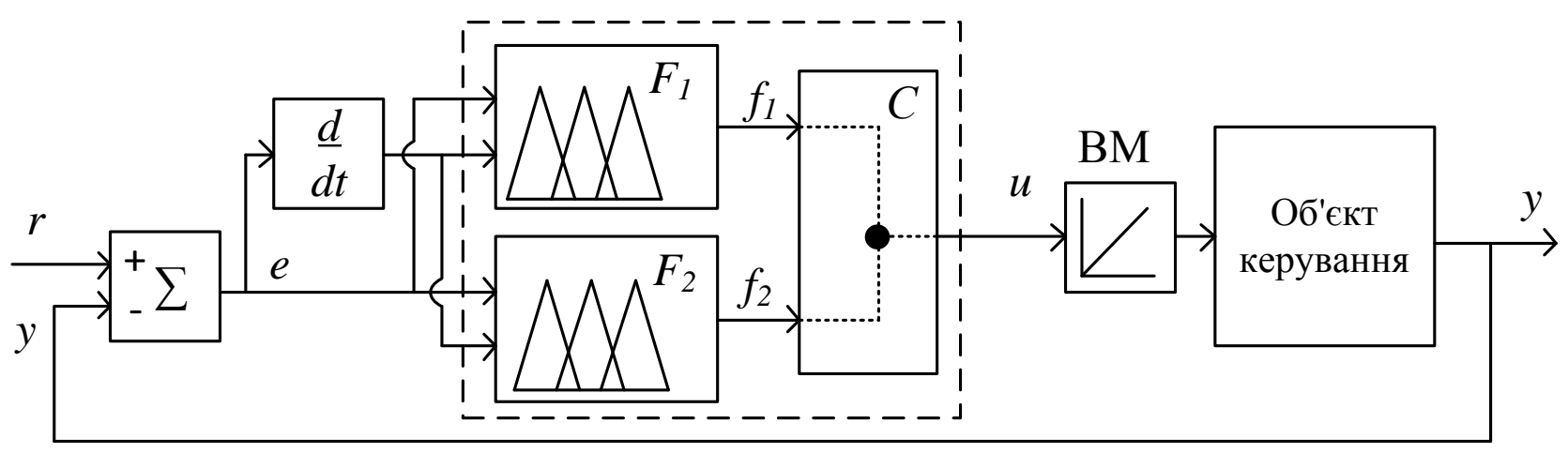

Рис. 1 - Схема $з$ двоканальним нечітким регулятором

При надходженні на входи двоканального нечіткого регулятора сигналу неузгодженості $e$ на виході блоку

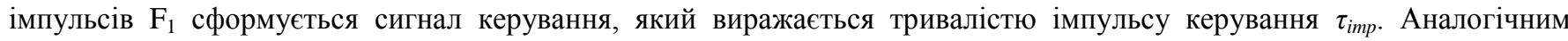
чином сформується сигнал тривалості пауз $\tau_{\text {раuse. }}$ При сталості вхідного сигналу $e$ тривалість імпульсів і пауз також буде незмінною, що показано на графіку залежності $\tau(t)$. В такому випадку сигнал на виході інтегратора буде мати поступово наростаючий вигляд, як це показано на графіку $u(t)$ рис. 2. Штрихова похила лінія відображає усереднення ступінчатого вихідного сигналу інтегратора. 


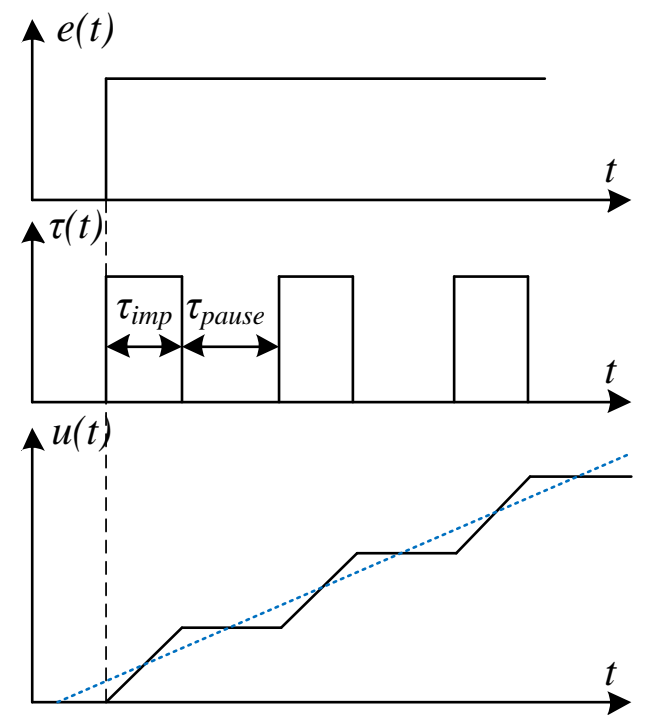

Рис. 2 - Формування вихідного сигналу нечіткого регулятора

Таким чином схему з двоканальним нечітким регулятором, в більшості випадків, з достатньою точністю, можна звести до одноконтурної схеми регулювання з інтегральним регулятором, в якій коефіцієнт підсилення $\epsilon$ змінним параметром залежно від вхідних сигналів.

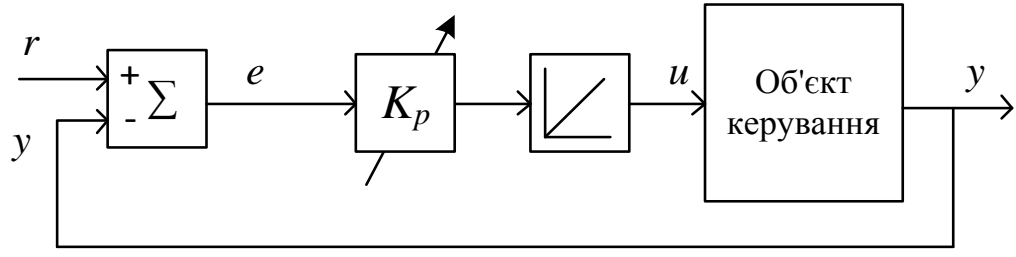

Рис. 3 - Схема керування зі змінним коефіцієнтом підсилення регулятора

Структури з підлаштуванням одного або декількох параметрів залежно від зовнішніх факторів правомірно відносити до адаптивних систем керування [6]. На рис. 4 наведена схема, яка пояснює, яким чином відбувається автопідлаштування коефіцієнту підсилення $K_{p}$ інтегрального регулятора.

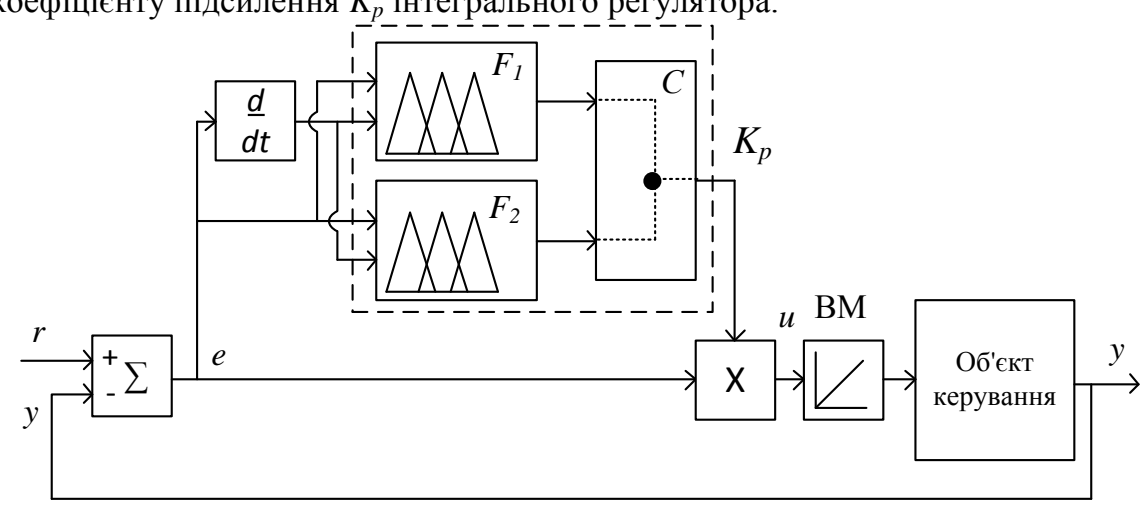

Рис. 4 - Схема з адаптивним підлаштуванням коефіцієнту підсилення регулятора

В ній як ланка інтегрування виступає виконавчий механізм зі своєю сталою часу інтегрування, а швидкість зміни положення регулювального органу можна змінювати за рахунок зміни коефіцієнту підсилення $K_{p}$. Залежно від сигналу помилки $e$, швидкості його зміни $d e / d t$ і бази правил fuzzy-блоків адаптації $F_{1}$ і $F_{2}$ коефіцієнт $K_{p}$ змінюється від деякого максимального значення $K_{\text {ртах }}$ до нуля.

\section{Апроксимація вихідного сигналу двоканального нечіткого регулятора}

Для оцінки стійкості системи з двоканальним нечітким регулятором необхідно визначити, при яких значеннях вхідних змінних комбінація імпульсу і паузи будуть давати найбільше сумарне переміщення виконавчого механізму. Відповідно до рис. 5 комбінація імпульсів і пауз буде формувати ступінчатий сигнал керування, який буде характеризуватися найбільшою швидкістю наростання. 


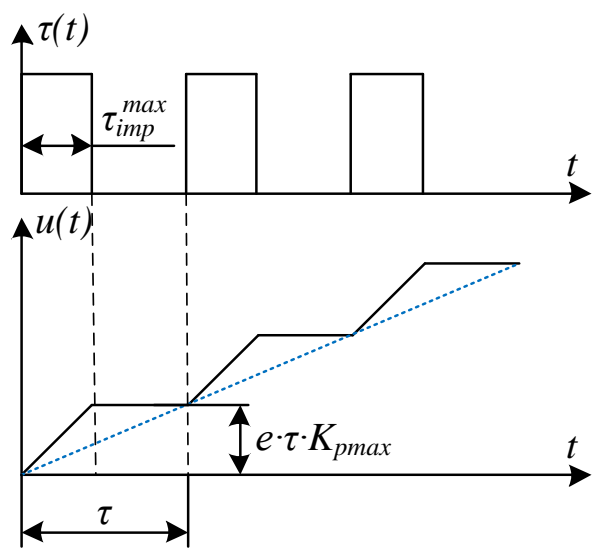

Рис. 5 - Еквівалентність вихідних сигналів інтегрального регулятора і нечіткого регулятора

Еквівалентним цьому сигналу є сигнал у вигляді прямої, кут нахилу якої визначається величиною сигналу неузгодженості $e$ i значенням параметра $K_{p}^{\max }$ інтегрального регулятора. Задача оцінки стійкості зводиться до визначення критичного параметра $K_{p}^{\kappa p}$, при якому система виходить на границю стійкості і порівняння цього параметра з $K_{p}^{\max }$.

Для визначення критичного значення $K_{p}{ }^{\kappa p}$ зручно користуватися частотним критерієм якості, що визначає запас стійкості системи автоматичного керування за підсиленням Gm (Gain margin) [7, 8]:

$$
G m=\frac{1}{\left|W_{P C}\left(\omega_{\pi}\right)\right|}
$$

де $\left|W_{P C}\left(\omega_{\pi}\right)\right|$ - модуль АФЧХ розімкнутої системи на частоті, що відповідає куту $180^{\circ}$ повороту вектора АФЧХ.

Якщо значення модулю АФЧХ $\left|W_{P C}\left(\omega_{\pi}\right)\right|$ визначати при $K_{p}=1$, то критичне значення $K_{p}^{\kappa p}$ буде дорівнювати запасу стійкості за підсиленням Gm:

$$
K_{P}^{\kappa p}=G m=\frac{1}{\left|\begin{array}{c}
W_{P C}\left(\omega_{\pi}\right) \mid \\
K_{P}=1
\end{array}\right|}
$$

Система 3 двоканальним нечітким регулятором може вважатися стійкою в усьому діапазоні вхідних змінних, якщо максимальна швидкість наростання сигналу керування є меншою, ніж швидкість наростання сигналу керування інтегрального регулятора з параметром $K_{p}{ }^{\kappa p}$ (див. рис. 6).

Відповідно, якщо швидкість наростання сигналу керування є більшою, ніж у еквівалентної схеми 3 інтегральним регулятором, то система в цьому діапазоні вхідних змінних вже працює за межею стійкості.

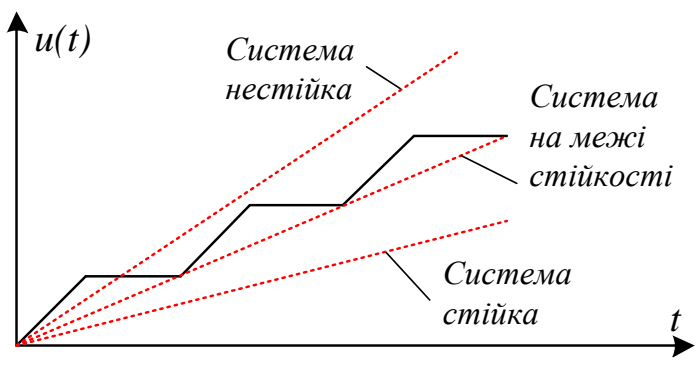

Рис. 6 - Сигнал керування двоканального нечіткого регулятора (суцільна лінія), сигнал керування інтегрального регулятора на межі стійкості (пунктирна лінія)

Якщо швидкість наростання сигналу керування співпадає з швидкістю зміни сигналу керування еквівалентної схеми з інтегральним регулятором, то система в цьому діапазоні вхідних змінних працює на межі стійкості.

Недоліком апроксимації вихідного сигналу двоканального нечіткого регулятора перехідною характеристикою інтегрального регулятора є те, що вихідний сигнал нечіткого регулятора апроксимується прямою, яка проходить по "нижнім" крайнім точкам. Це є причиною уповільнення реакції еквівалентного регулятора, що показано в [5].

Більш точним наближенням вихідного сигналу двоканального нечіткого регулятора $є$ вихідний сигнал ПІрегулятора, заміст І-регулятора (рис. 7). В цьому випадку також однозначно можна визначити параметри налаштування регулятора $K_{\Pi I}$ і $T_{\Pi I}$. 


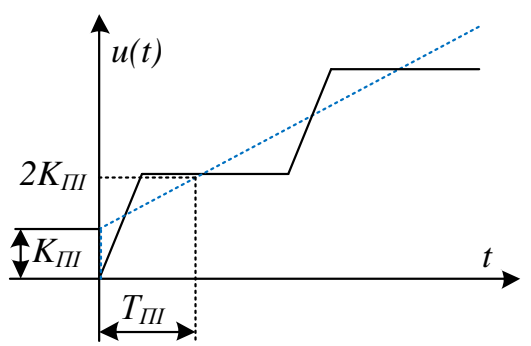

Рис. 7 - Апроксимація вихідного сигналу нечіткого регулятора сигналом ПІ-регулятора, $\kappa_{I I I}-$ коефіцієнт підсилення регулятора, $T_{\boldsymbol{I I}}$ - стала часу інтегрування

Для цього вихідний сигнал двоканального нечіткого регулятора слід апроксимувати лінійною залежністю,

$$
y=a x+b
$$

яку зручно визначити за допомогою методу найменших квадратів. Для розрахунку коефіцієнтів рівняння (3) достатньо чотирьох точок, які однозначним чином визначаються за значеннями тривалості імпульсу і паузи (рис. 8).

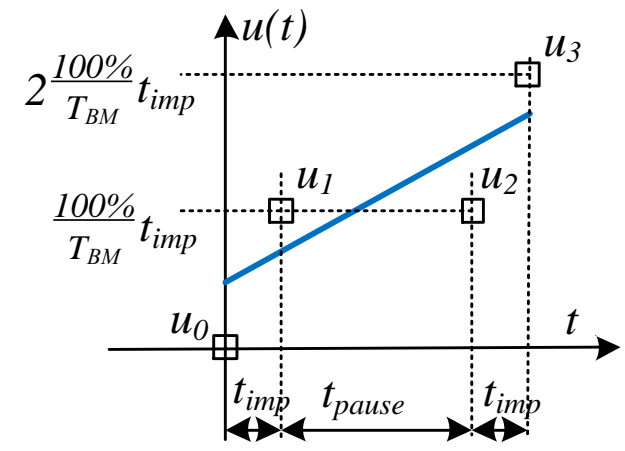

Рис. 8 - Апроксимація вихідного сигналу нечіткого регулятора методом МНК

Коефіцієнти рівняння (3) визначаються за наступними формулами:

$$
\begin{gathered}
a=\frac{\sum_{i=0}^{3} t_{i} \sum_{i=0}^{3} u_{i}-4 \sum_{i=0}^{3} u_{i} t_{i}}{\left(\sum_{i=0}^{3} t_{i}\right)^{2}-4 \sum_{i=0}^{3} t_{i}^{2}} \\
b=\frac{\sum_{i=0}^{3} t_{i}^{2} \sum_{i=0}^{3} u_{i}-\sum_{i=0}^{3} t_{i} \sum_{i=0}^{3} u_{i} t_{i}}{4 \sum_{i=0}^{3} t_{i}^{2}-\left(\sum_{i=0}^{3} t_{i}\right)^{2}}
\end{gathered}
$$

При структурі ПІ-регулятора:

$$
W_{p}(s)=K_{\Pi I}\left(1+\frac{1}{T_{\Pi I} s}\right)
$$

налаштування ПІ-регулятора розраховуються як:

$$
K_{\text {III }}=\left|\frac{b}{e}\right|
$$

де $e$ - значення сигналу неузгодженості, для якого проводиться розрахунок,

$$
T_{\Pi I}=\left|\frac{1}{\frac{a}{K_{\Pi I} e}}\right|
$$

Таким чином, для всього діапазону вхідних змінних можна розрахувати налаштування ПІ-регулятора, після чого не важко визначити необхідні характеристики системи керування, наприклад, запас стійкості за модулем $G m$. 


\section{Дослідження стійкості системи з двоканальним нечітким регулятором}

На рис. 9a-9в наведені значення запасів стійкості за модулем для системи регулювання температурного режиму прямоточного котлоагрегату потужністю 300 МВт. Система регулювання побудована на базі двоканального нечіткого регулятора, тому для дослідження стійкості використана вище викладена методика. Рисунки 9a-9в зображують контури поверхонь, які визначаються залежністю:

$$
G m=f\left(e, \frac{d e}{d t}, N\right)
$$

де $G m$ - запас стійкості за підсиланням; $e$ - сигнал неузгодженості, $d e / d t-$ похідна від сигналу неузгодженості, $N$ поточне навантаження енергоблоку.

Для різних навантажень енергоблоку визначені робочі діапазони зміни вхідних параметрів системи. При

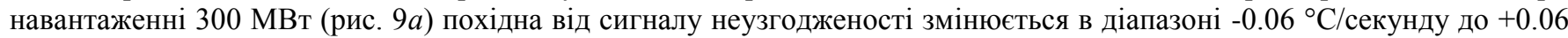
${ }^{\circ} \mathrm{C} /$ секунду. При середньому значенні навантаження 265 МВт (рис. 9б) похідна від сигналу неузгодженості змінюється в діапазоні $-0.2{ }^{\circ} \mathrm{C} /$ секунду до $+0.2{ }^{\circ} \mathrm{C} /$ секунду, що пояснюється зміною динамічних властивостей контурів регулювання $[9,10]$. При мінімальному значенні навантаження 225 МВт (рис. 9в) похідна від сигналу неузгодженості змінюється в найширшому діапазоні $-0.3{ }^{\circ} \mathrm{C} /$ секунду до $+0.3{ }^{\circ} \mathrm{C} /$ секунду.

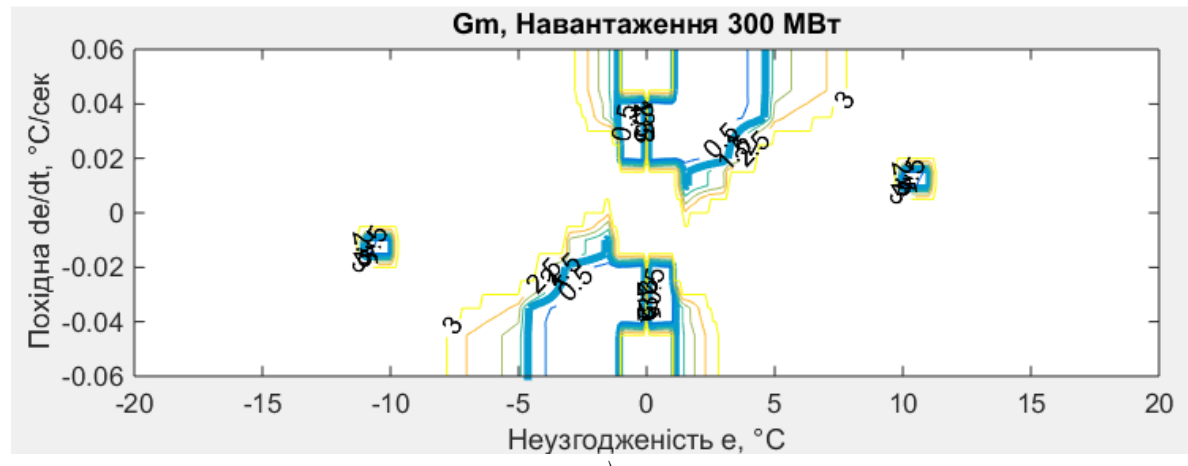

a)

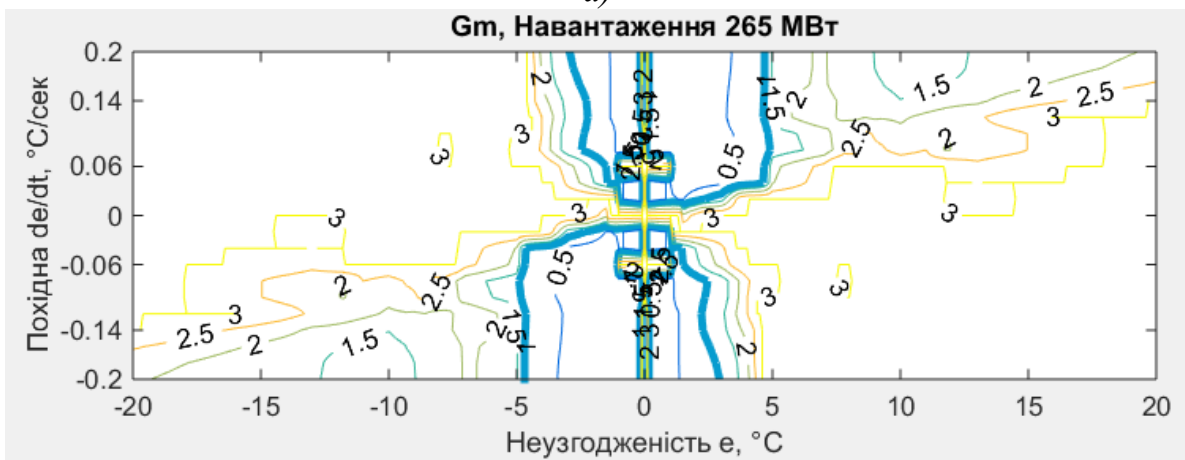

б)

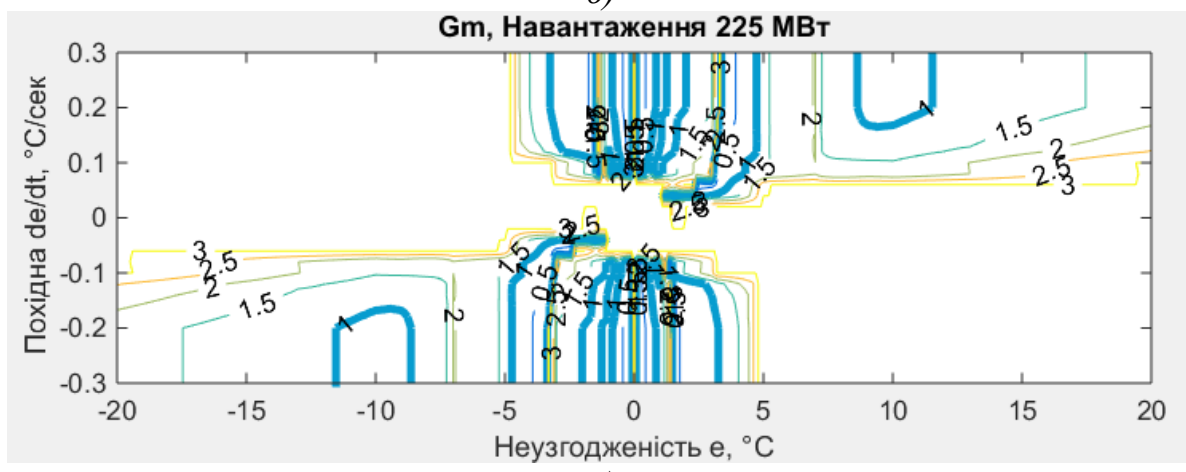

в)

Рис. 9 - Контури поверхонь запасів стійкості за модулем Gm системи 3 двоканальним нечітким регулятором а) навантаження 300 МВТ, б) навантаження 265 МВТ, в) навантаження 225 МВТ

Значення $G m=1$ (жирний контур синього кольору) означає, що система знаходиться на межі стійкості, при $G m<1$ система є нестійкою. Контури при $G m>3$ не зображені. Такі значення відповідають надмірним запасам стійкості, тому 
вони не наводяться, щоб не завантажувати рисунок зайвою інформацією. На рис. 9 наглядно зображено, в яких діапазонах регулятор має форсовані налаштування. Особливу цікавість на даних поверхнях викликають ділянки значень Gm при однознакових значеннях сигналів $\boldsymbol{e}$ та $\boldsymbol{d e} / \boldsymbol{d t}$, які відповідають фазі відхилення технологічного параметра від уставки. Завдяки форсованим налаштуванням нечіткого регулятора досягається збільшення швидкості реакції системи керування на збурення порівняно зі стандартним ПІД-регулятором 3 фіксованими налаштуваннями (рис. 10). При зміні знаку першої похідної $\boldsymbol{d e} / \boldsymbol{d t}$, тобто коли технологічний параметра прямує до значення уставки, налаштування нечіткого регулятора змінюються на більш "грубі" для уникнення появи автоколивань, забезпечуючи стійкість системи керування. Дане дослідження стійкості системи 3 двоканальним нечітким регулятором яскраво демонструє гнучкість двоконтурної схеми регулятора при формуванні сигналу керування на об'єкт. Вона дозволяє розмежувати задачі форсованого керування на початковій фазі перехідного процесу і стабілізації вихідної величини на завершальній стадії.

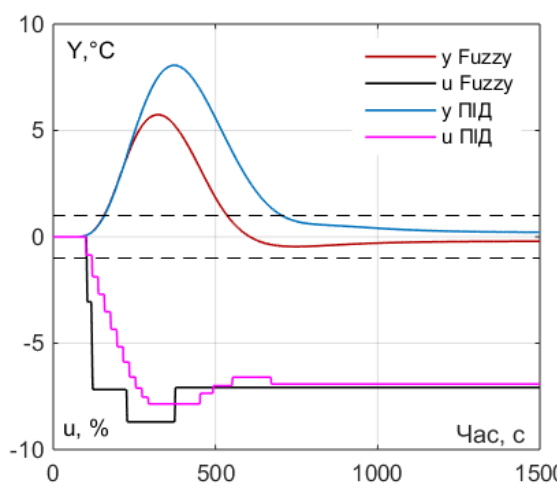

a)

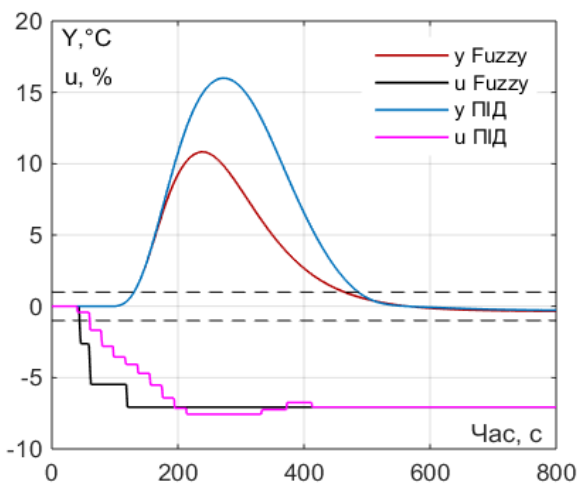

б)

Рис. 10 - Перехідні процеси системи регулювання температурного режиму a) при навантаженні 300 МВт, б) при навантаженні 225 МВт

y Fuzzy - перехідний процес в системі з двоканальним нечітким регулятором, u Fuzzy - сигнал керування в системі 3 двоканальним нечітким регулятором, у ПІД - перехідний процес в системі з ПІД-регулятором, и ПІД- сигнал керування в системі з ПІД-регулятором

\section{Висновки}

1. Запропоновано методику аналізу стійкості системи автоматичного керування 3 двоканальним регулятором. Обгрунтовано можливість представлення схеми 3 двоканальним нечітким регулятором як еквівалентної схеми 3 адаптивним I- або ПІ-регулятором. Розроблено аналітичні залежності між вихідними параметрами двоканального нечіткого регулятора і налаштуваннями ПІ-регулятора.

2. Для системи з адаптацією налаштувань регулятора розроблено підхід аналізу стійкості, який грунтується на тому, що в основному контурі регулювання відсутні нелінійні елементи. При такому припущенні для кожної комбінації налаштувань регулятора систему керування можна розглядати як лінійну. Це в свою чергу дозволяє застосовувати класичні методи аналізу стійкості з лінійної теорії автоматичного керування.

3. Розроблена методика аналізу стійкості системи з двоканальним нечітким регулятором яскраво демонструє гнучкість двоконтурної схеми регулятора при формуванні сигналу керування на об'єкт. Застосування двоканального нечіткого регулятора дозволяє розмежувати задачі форсованого керування на початковій фазі перехідного процесу і стабілізації вихідної величини на завершальній стадії. Запропонована методика аналізу стійкості не надає однозначної відповіді про стійкість системи керування в цілому, а є точковим рішенням. Більш повний аналіз стійкості системи 3 двоканальним нечітким регулятором в цілому може бути отриманий за допомогою імітаційного моделювання.

Список використаних джерел:

[1] Архангельський В., Богаенко И., Грабовский Г., Рюмшин Н. Системы фуцци-управления. Киев, 1997.208 с.

[2] Белоглазов А., Косенко Ю. Анализ методов устойчивости нечетких систем управления. Известия ЮФУ. Технические науки. 2013. № 2(139). С. 127-132.

[3] Манчук Д., Черный С. Анализ устойчивости нечетких систем управления в малом, большом, в целом. Современные наукоемкие технологии. 2014. № 5 Ч.1. С. 74-75.

[4] Ладанюк А., Власенко Л., Луцька Н., Смітюк Я. Проблема забезпечення стійкості інтелектуальних систем керування технологічними об’єктами. Наукові пращі НУХТ. 2019. Том 25, № 2. С. 7 - 15. https://doi.org/10.24263/2225-2924-2019-25-2-3.

[5] Новіков П. В. Автоматизація процесів керування інерційними контурами котлоагрегата теплової електростанції 3 використанням двоканального нечіткого контролера : дис. ... канд. техн. наук : 05.13.07 / Національний технічний університет України "Київський політехнічний інститут імені Ігоря Сікорського". Київ, 2019. 191 с. 
[6] Штіфзон О., Новіков П., Баган Т. Розробка адаптуючого fuzzy-logic пристрою для керування в умовах параметричної нестаціонарності. Східно-європейський журнал передових технологій. Харків, 2018. Том 1 № 2. C. 30-37. https://doi.org/10.15587/1729-4061.2018.121749.

[7] Michael Mulholland. Applied Process Control: Essential Methods 1st Edition. 2016. p. 460.

[8] Åström KJ, Hägglund T. Advanced PID Control. ISA - The Instrumentation, Systems and Automation Society. 2006. p. 460

[9] Коновалов М.А., Бунке А.С. Основы новой стратегии синтеза систем оптимального управления. Киев, 2014.280 c.

[10] Kovrigo Yu., Konovalov M., Bunke A. Modernizing the heat load control system of a oncethrough boiler unit at a thermal power station using a dynamic corrector. Thermal Engineering. 2012. № 59(10). P. 772-778. https://doi.org/10.1134/S0040601512100072.

\title{
References:
}

[1] V. Arkhangelsky et al., Fuzzy-control systems. Kiev, 208 p., 1997.

[2] A. Beloglazov and Yu. Kosenko, "Study of stability of fuzzy management systems," in Izvestiya SFEDU. Engineering Sciences, no. 2(139), pp. 127-132, 2013.

[3] D. Manchuk and S. Chernyi, "Stability analysis of fuzzy control systems in a small, large, as a whole," in. Modern High Technologies, no. 5 (1), pp. 74-75, 2014. URL: http://top-technologies.ru/ru/article/view?id=33710 (Accessed: 29.05.2020)

[4] A. Ladanyuk et al., "The problem of ensuring the stability of intelligent control system of technological objects," in Scientific Works of NUFT, vol. 25, iss. 2, pp. 7-15, 2019.doi: https://doi.org/10.24263/2225-2924-2019-25-2-3.

[5] P. Novikov, "Control processes automation of thermal power plant unit inertial channels using a two-channel fuzzy controller," Ph.D. dissertation, National Technical University of Ukraine "Igor Sikorsky Kyiv Polytechnic Institute", Kyiv, Ukraine, 2019.

[6] O. Shtifzon et al, "Development of the adaptive fuzzy-logic device for control system in conditions of parametric nonstationary plant," in Eastern-European Journal of Enterprise Technologies, 1/2 (91), pp. 30-37, 2018. doi: https://doi.org/10.15587/1729-4061.2018.121749.

[7] M. Mulholland. Applied Process Control: Essential Methods, 1st ed., 2016, 460 p.

[8] K.J. Astrom and T. Hagglund "Advanced PID Control," in The Instrumentation, Systems and Automation Society, p. 460, 2006.

[9] M. Konovalov and A. Bunke, Fundamentals of a new strategy for the synthesis of optimal control systems. Kyiv, 2014, $280 \mathrm{p}$.

[10] Yu. Kovrigo et al., "Modernizing the heat load control system of a oncethrough boiler unit at a thermal power station using a dynamic corrector," Thermal Engineering, vol. 59, pp. 772-778, Sep. 2012. doi: https://doi.org/ 10.1134/S0040601512100072.

\section{УДК 681.513;62.505;621.9.04}

\section{PASSIVE IDENTIFICATION OF MULTIVARIABLE STABILIZATION SYSTEM ELEMENTS' DYNAMICS}

\author{
Osadchy S. I. ${ }^{1}$, Zozulia V. A. ${ }^{2}$ \\ ${ }^{1,2}$ Central Ukrainian National Technical University, Kropyvnytskyi, Ukraine \\ ORCID: ${ }^{1}$ https://orcid.org/0000-0002-1811-3594, ${ }^{2}$ https://orcid.org/0000-0003-3793-4686 \\ E-mail: ${ }^{1}$ srg2005@ukr.net, ${ }^{2}$ irish38@ukr.net
}

Copyright (C) 2018 by author and the journal "Automation of technological and business - processes. This work is licensed under the Creative Commons Attribution International License (CC BY). http://creativecommons.org/licanses/by/4.0

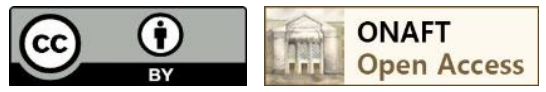

DOI: https://doi.org/10.15673/atbp.v12i1.1701 